\title{
Post-agrogenic evolution of soils in ancient Greek land use areas in the Herakleian Peninsula, southwestern Crimea
}

\author{
FN Lisetskii,' VF Stolba, ${ }^{2}$ EI Ergina, ${ }^{3}$ ME Rodionova' \\ and EA Terekhin'
}

\begin{abstract}
The paper examines the regularities of the post-agrogenic evolution of soils of differing age in the Herakleian Peninsula (southwestern Crimea, Ukraine), which developed under conditions of the sub-Mediterranean climate and have been cultivated since ancient times. Whether developed under steppe or sub-Mediterranean forest vegetation, the Crimean cinnamonic soils display different physico-chemical and geochemical characteristics after 1600 years under no cultivation. It is demonstrated that among 40 examined physico-chemical and geochemical soil characteristics, only ten are sufficiently informative to diagnose the post-agrogenic regime of a soil system. In the geographic and pedogenetic grouping of post-antique long-fallow soils, labile phosphorus content and the hue of soil colour prove to be of primary importance.
\end{abstract}

\section{Keywords}

ancient Greek land use, Chersonesos, cinnamonic soils, Crimea, long-fallow soils, old cultivated soils, soil evolution

Received I5 March 2012; revised manuscript accepted I3 August 2012

\section{Introduction}

In the late Holocene, evolutionary changes of soil in the areas of intensive and long-term agricultural development have occurred under the combined effect of natural and anthropogenic factors. One such region is the area of the Greek city-states of the northern Black Sea region, where the study of soil and land opens up new possibilities for understanding the synergetic (natural and anthropogenic) effects in environmental changes, which are reflected in the 'memory' (morphology and properties) of soil. The formation of agrolandscape systems is defined by both singular natural and anthropogenic elements and such systemically interrelated territorial features as systems of land use, communication routes, settlement patterns, etc. (Bučas and Danjulajtis, 1984). Among the most efficient methods of identifying ancient land use systems is remote sensing (Adamesteanu and Vatin, 1976; Karjaka, 2008; Ščeglov, 1980; Šiškin, 1982).

The remains of ancient land-division systems have been revealed by remote sensing in various parts of the Mediterranean and adjacent areas, including the northern Black Sea littoral. However, owing to the prevalence of loose parent materials (loess and loess-like loams), such traces can easily become obliterated in this region, which considerably complicates their identification in the terrain. Thus, although traces of ancient land division in the Greek rural territories of the Lower Dniester, Lower Dnieper and Southern Bug are discernible in aerial photographs, attempts to identify them on the ground have proved ineffective (Brujako et al., 1991). Important results have been achieved by complex studies on the Taman Peninsula, where remote sensing and identification of division walls in the terrain were supplemented by their examination in trenches (Garbuzov et al., 2004). However, the best opportunity for the study of ancient land use is offered by the rural territory of Chersonesos on the Herakleian Peninsula (southwestern Crimea), where the planting and division walls of land plots, as well as ruins of numerous farmhouses, are still distinctly discernible.

Soils cultivated in antiquity (both ploughed and post-agrogenic long-fallow) preserve reliable differences from their virgin equivalents in a number of parameters. The well-determinable distinctiveness of these acquired properties (Lisetskii, 2008) enables their identification even after they have been subjected to more intensive mechanical treatment over the last 100-130 years.

In the long-fallow lands of post-antiquity times, territorially distributed combinations of soil and vegetation cover are most informative. The secondary succession (the recovery of plant communities on regenerating soil) can be assigned (Goleusov and Lisetskii, 2009) to regenerative plant succession in the process of recent soil formation. It has been argued (Ljuri et al., 2010) that in forest-steppe cover on typical chernozems the climax of this process is reached in 50-60 years, while on the dry steppes on chestnut soils (kastanozems) it may take 100-150 years and longer. In the rural territories of some Greek centres on the northern Black Sea coast (Tyras, Olbia and Bosporos), the phytoproductivity of steppe ecosystems formed on long-fallow land of different age was studied by Lisetskii (1998). It was demonstrated that the effects of perennial agriculture were not completely obliterated after several centuries or even after one or two millennia of a

\footnotetext{
'Belgorod State National Research University, Russia

${ }^{2}$ Aarhus University, Denmark

${ }^{3}$ Vernadskii Taurida National University, Ukraine
}

\section{Corresponding author:}

VF Stolba, Aarhus University, Nordre Ringgade I, DK-8000 Aarhus C, Denmark.

Email: klavs@hum.au.dk 


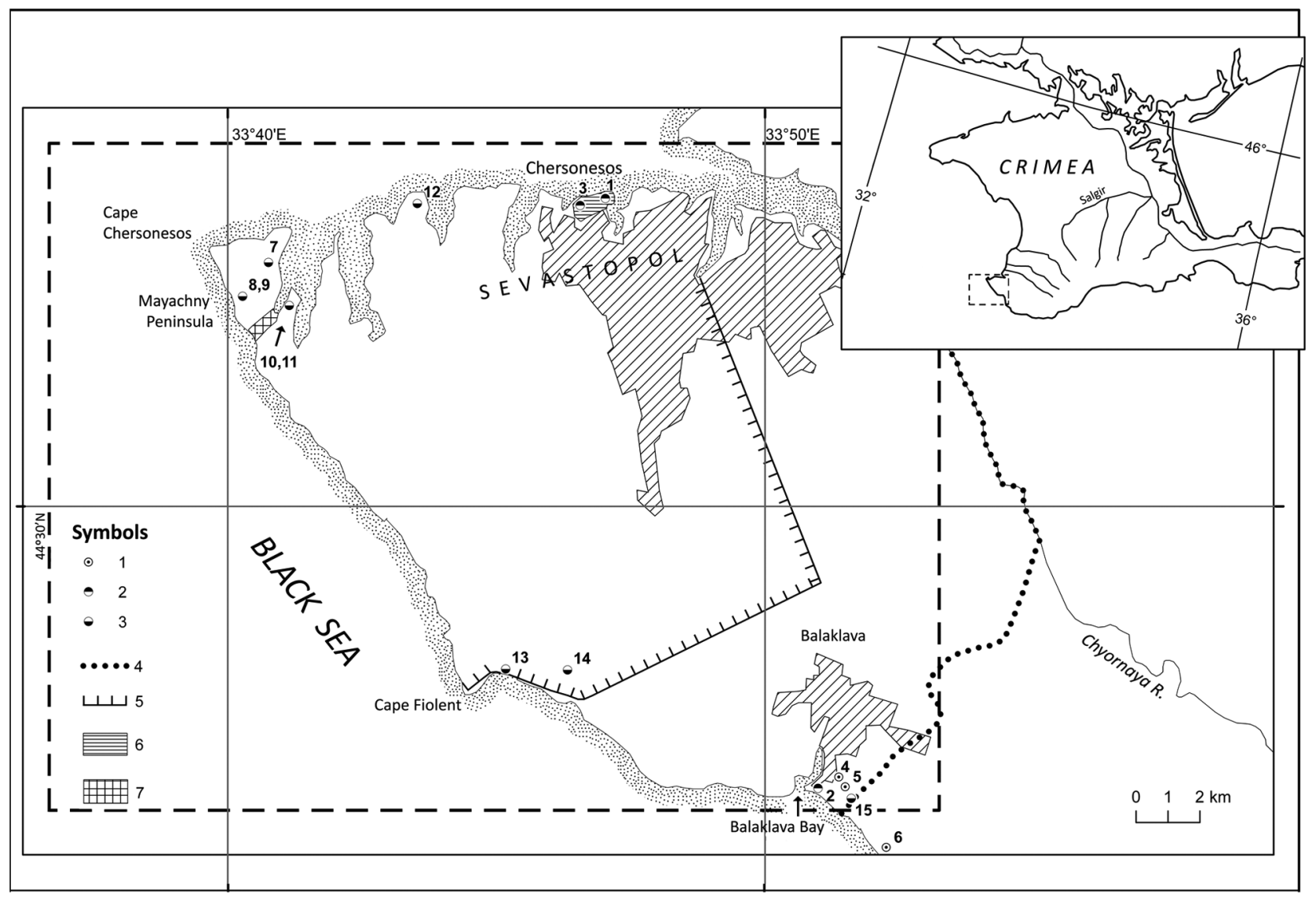

Figure I. Herakleian Peninsula and study objects. I-3: sampled sites (see Table I), including: I: steppe and forest soils as well as arable soils outside the chora of Chersonesos; 2: soils of different age on archaeological sites; 3: post-agrogenic soils. 4: Limits of Herakleian Peninsula. 5: Approximate limits of divided territory of the nearby Chersonesos chora. 6:Town site of Chersonesos. 7: Strabo's 'Old Chersonesos'.

long-fallow regime, because of the absence of equilibrium in the soil system, which preserves the agrogenic impacts in its profile structure and properties.

The particular properties of post-agrogenic soils in the context of natural soil development in the late Holocene have not been sufficiently studied. The present study aims to define the character of the natural and post-agrogenic evolution of cinnamonic soils during the late Holocene, and to identify the most informative physico-chemical and geochemical indicators for diagnosing persistent transformations in the soil system under long-term (multicentennial) agrogenic impacts.

\section{Conditions of pedogenesis}

The Herakleian Peninsula, located in southwestern Crimea (Figure 1), is unique not only for its peculiar soil-climatic interrelations, but also for its long history of impacts, including agricultural and military use. With an area of c. $126 \mathrm{~km}^{2}$, the Herakleian Peninsula forms part of the Chyornaya River physicogeographical region of the Crimean piedmont forest-steppe province (Podgorodeckij, 1988). The terrain is dominated by a cuesta landscape with cinnamonic soils and shiblyak vegetation (a local equivalent of the Mediterranean maquis). While differentiating the Herakleian cuesta xerophytic-phrygana landscape, Ena et al. (2004) consider lithosols to be predominant here. More accurately, the peninsula's principal landscapes can be defined as structurally denuded foothills on Neogenic limestones, with cinnamonic soils and rendzinas under bushes, juniper forests, phrygana and mixed-herbs steppes (Bagrov and Rudenko, 2003).

The region's climate is very dry and moderately hot, with fairly mild winters. With an annual precipitation of $350-475 \mathrm{~mm}$ and an average annual temperature of $10.3-12.0^{\circ} \mathrm{C}$ (cf. $20.6-$ $23.0^{\circ} \mathrm{C}$ for July, $0.1-2.0^{\circ} \mathrm{C}$ for February), the sum of active temperatures $\left(\Sigma t>10^{\circ} \mathrm{C}\right)$ amounts to $3300-3500^{\circ} \mathrm{C}$ and the number of frost-free days to 180-238 (Kočkin et al., 1972), the precipitation-evaporation ratio being equal to 0.42 . This climate differs from the Mediterranean climate in several respects. First, $\Sigma t>$ $10^{\circ} \mathrm{C}\left(3500^{\circ} \mathrm{C}\right)$ is lower than the conventional norm for the Mediterranean, which is at least $4000^{\circ} \mathrm{C}$; second, the temperature of the coldest month is $2.6^{\circ} \mathrm{C}$, which in the Mediterranean is no less than $4^{\circ} \mathrm{C}$; and third, the summer precipitation slightly exceeds that of the winter (Bagrova et al., 2003).

In the local conditions of the Herakleian peninsula, the climatically determined appearance of sub-Mediterranean vegetation, under which corresponding soils began to form, is dated to $c$. 7.5$6.5 \mathrm{ka} \mathrm{BP}$ (Cordova, 2007; Cordova and Lehman, 2005). The oak and juniper/pistachio open woodlands and shiblyak vegetation (Carpinus orientalis, Paliurus spina-christi, Crataegus), in combination with a cuesta relief, are characteristic of the western piedmont type of sub-Mediterranean landscapes (Bagrova et al., 2003).

The background soils, gravelly cinnamonic soils and rendzinas of dry forests and shrubs extend up to an altitude of 400-550 $\mathrm{m}$ above sea level. The thickness of the humus-accumulative horizon ranges between 5 and $20 \mathrm{~cm}$; it has a grainy-powdery structure, and strong brown (7.5 YR 5/6) or light brownish grey (10 YR 6/2) colour.

The study area includes almost the entire Herakleian peninsula, which from the 4th to the 2nd centuries BC constituted the nearby chora of Chersonesos (Nikolaenko, 2006). The area's eastern boundary runs along the Chyornaya river valley for a distance of $7 \mathrm{~km}$ from its mouth, and continues along the western bench of low mountains east of Balaklava to the Black Sea shore. 


\section{Land management in the Greek period}

While recent archaeological discoveries push the foundation of Chersonesos back to the late 6th century BC (Stojanov, 2007; Vinogradov and Zolotarev, 1999; Zolotarev, 1996), there is still no positive evidence for the city's agricultural activity within the first century and a half following foundation. The earliest signs of such evidence are the traces of a land division identified in a 3-4 $\mathrm{km}$ wide zone around the city-site of Chersonesos, on the Mayachny Peninsula, in the area of Bay Omega northwest of the road connecting Lighthouse Point and the city, and also in the Berman Ravine (Nikolaenko, 1999: 25-30; 2001b: 192-195; 2006: 156, figure 5), dating probably from around 360-350 BC. The superbly preserved grid, dividing most of the Herakleian Peninsula into about 430 large rectangular plots separated by stone roads, marks the next phase in the area's development, taking place in the third quarter of the 4th century BC. Clearly discernible in aerial photographs, satellite imagery and in the terrain, the planting and interior division walls, as well as the walls surrounding the plots, are built of stone collected from the fields. Each large plot was subdivided into six smaller parcels measuring $210 \mathrm{~m}$ on one side, corresponding to a parcel area of 4.4 ha. The same standard module of c. 4.4 ha has presumably been employed in the distant chora of Chersonesos in northwestern Crimea. Measuring 10,660 ha and limited by the Yuzhnaya Bay to the northeast and the Karan' Heights to the southeast, the demarcated territory of the adjacent chora encompasses about 140 well-preserved farmhouses (some of them fortified), which the absence of accompanying burial sites suggests were probably occupied only seasonally (e.g. Carter, 2006: 180).

A string of roughly contemporary indigenous sites identified along the periphery of this land and on the eastern slopes of Mount Sapun (Kravčenko, 2005; Savelja, 1996; Zubar' and Kravčenko, 2003) belongs to the Kizil-Koba archaeological culture associated with the ancient Taurians. Although they are thought to have had dependent or semi-dependent status similar to that of the Helots of Messenia and Laconia (Chtcheglov, 1992: 228-230), the actual character of their relationship with the Greek city, as well as the issue of the local labour force and the nature of land ownership, is still far from clear.

Unlike northwestern Crimea, which was the city's main grainproducing area and is referred to in the ancient sources as 'the plain' (to pedion) (IOSPE I' $, 401,418$ ), the Herakleian Peninsula, with its thin and stony soils, is generally unsuitable for cultivating cereals. This agrees with a fairly scarce presence of Tr. aestivocompactum in the paleobotanical record (Janushevich and Nikolaenko, 1979), although recently retrieved pollen data seem to suggest somewhat larger cultivation of cereals in the floodplain of the Chyornaya River (Cordova and Lehman, 2006: 437). Numerous finds of wineries and containers for fermentation (Strželeckij, 1958: 165, figure 11, 1961; Nikolaenko, 2006), fossil pollen (Cordova and Lehman, 2003, 2006: 436-438) and paleobotanical data (Januševič, 1986: 40-70; Janushevich and Nikolaenko, 1979; Yanuchevitch et al., 1985), as well as local production of transport amphorae, often stamped with the names of officials (Monachov, 1989; Stolba, 2005a), attest viticulture, supplemented by such cultivars as fruit trees and pulses, as a main agricultural specialization of the city's adjacent chora in the Hellenistic period. This farming is very likely to have been complemented by animal husbandry and other economic activities; these, however, still call for an unambiguous archaeological and paleozoological proof.

It is not until the Roman and Byzantine periods, as indicated by increased frequencies of cereal pollen in the deposits of that time (Cordova and Lehman, 2006: 439), that cereal cultivation in the area gains any importance - probably as an adaptation response to the city's lost access to its former rural territories in northwestern Crimea.
As at present, water supply must have been a major problem for the ancient occupants of the Herakleian peninsula. Natural springs in the area are rare, being recorded in the upper reaches of the Khomutova, Sarandinaki, Yukharin and Berman ravines. Ancient wells and water cisterns are also attested at a number of farms (Nikolaenko, 2001a). Studies on the western slope of the Sarandinaki ravine have revealed a ceramic water duct traced for a distance of over $3 \mathrm{~km}$ (Bilde et al., 2008: 137; Kovalevskaja, 1994; cf. Moiseev, 1926: 120). The possibility of irrigation by means of water-retaining barrages across the ravines has been alleged (Moiseev, 1926), although it has proved impossible to ascertain it archaeologically (Cordova and Lehman, 2006: 438). Beside their other functions (such as improving technological soil quality, increasing depth of planting beds and retaining rain water: Strželeckij, 1961: 69-72), the narrowly spaced stone planting walls built inside the individual plots might also have compensated for the water deficit to a certain extent by significantly increasing the surface on which water vapour from the air could condense as dew.

Despite the city's remarkable longevity, its life was repeatedly shattered by recurring crises, caused both by natural factors such as probable climate deterioration in the 3rd century $\mathrm{BC}$ (Stolba, 2005b, 2005c) and internal political instability (IOSPE $\left.\mathrm{I}^{2}, 401\right)$, as well as continual wars with the Scythians, to which only the intervention of the Pontic king Mithridates VI Eupator put an end (Strabo 7.4.7; IOSPE I'2, 352, 353). All this accounts for a discrete character in the peninsula's agricultural use, with periods of protracted, several-decades long disruptions and significant contractions of the chora.

The agrolandscapes of different age formed during the lifespan of ancient Chersonesos and medieval Cherson is an agricultural monument that requires protected status as an object of historical and cultural heritage. The continuous transformation of the vegetation cover around the city justifies the search for a genetic relationship between the modern 'steppe' flora and the agrarian influences of the past (Yena et al., 2006).

\section{Methods}

The study objects included (1) anthropogenically transformed soils inside the ancient land plots; (2) soils of different age formed on cultural layers of archaeological and historical sites (such as the embankment of a French artillery battery of 1855 , renewed in 1905 (the Canet guns battery), the Genoese fortress of Cembalo and the townsite of Chersonesos (east of the Western Basilica)); and (3) their zonal equivalents outside the limits of the Herakleian peninsula.

The numeration of ancient land plots in Table 1 follows Nikolaenko (1999). The boundaries of the soil zones in Figure 2 derive from the map 'Soils of the Crimean Oblast' (scale 1:200,000, compiled by the Ukrzemproekt Institute, Kiev, 1967). The present-day structure of the land fund has been obtained from a QuickBird-2 satellite image (27 July 2009, $2 \mathrm{~m}$ resolution). As the high image resolution resulted in a very cluttered picture, visual identification of land types was preferred to automatic decoding. The areas of the main types discerned were calculated in ArcGIS 9.3, and positions of the sampled sites were recorded with Garmin GPS (Figure 1, Table 1).

Soil analyses were performed by standard methods: the total carbon content and fractional composition of humus by Tyurin's method; the bulk nitrogen content $(\mathrm{N})$ by Kjeldahl's procedure; evaluation of $\mathrm{CO}_{2}$ in carbonates by acidometry; and evaluation of labile compounds of phosphorus by Machigin's method. The coefficient of water resistance $(W)$ was calculated for agriculturally valuable structural unities (ranging between 0.5 and $5 \mathrm{~mm}$ ) 


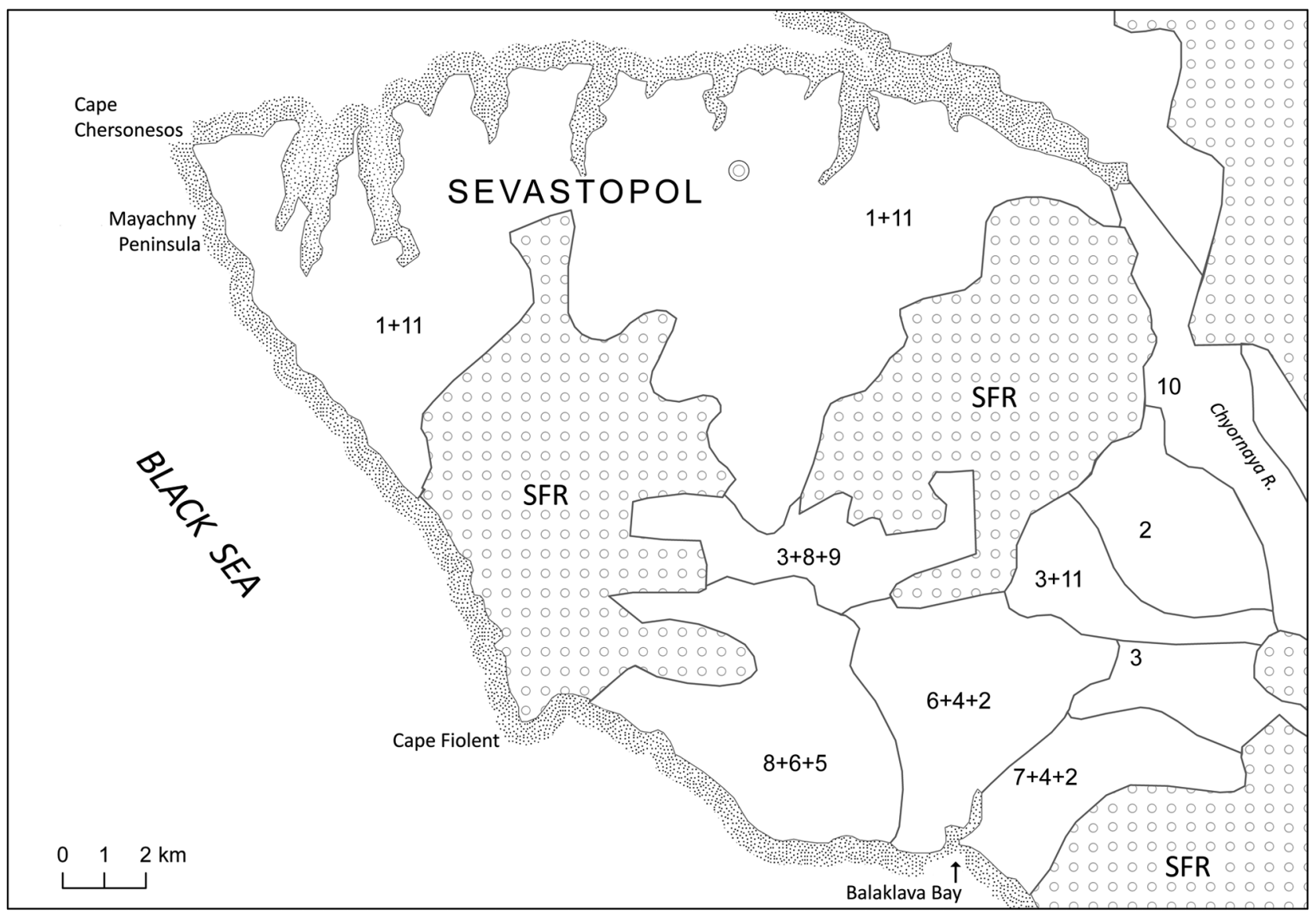

Figure 2. Soils of Herakleian Peninsula. I: Mountain cinnamonic, light-clayed, gravelly, carbonate soils; 2: mountain cinnamonic carbonate soils on eluvia and deluvia of carbonate rocks; 3 : mountain cinnamonic soils on carbonate deluvia; 4 : mountain cinnamonic loamy uncarbonated soils; 5: mountain cinnamonic uncarbonated soils on eluvia of sandstones; 6: mountain cinnamonic slightly saline soils on deluvia; 7: mountain cinnamonic, medium or strongly saline soils on saline clays; 8: soddy carbonated soils on eluvia of dense carbonate rocks; 9: meadow chernozem-like light-clayed soils; 10: meadow carbonated soils; I I: rock outcrops; SFR: State Forest Reserve.

(Dospechov et al., 1987). Bulk chemical composition of the soils and rocks was measured by XRF (Spectroscan Max-GV).

The microelement accumulation capability, determined as proposed by Shaw (1964), is a relation of a group of elements in the soil and serves as an average quantitative estimate of the soil's capability to accumulate the elements, as compared with that of the lithosphere. We use a modification of this factor, whereby its total value is determined not as an arithmetical mean but as a geometrical mean value $(R)$ :

$$
R=\sqrt[7]{\Pi \frac{S_{i}}{P_{i}}},
$$

where $S_{i}$ and $P_{i}$ are the contents of each microelement (Mn, $\mathrm{Zn}, \mathrm{Cu}$, $\mathrm{Ti}, \mathrm{Ni}, \mathrm{Cr}$ and $\mathrm{V}$ ) in the soil and soil-forming rock, respectively. For statistical analysis of soil colour, Munsell codes were converted to numerical values (Judd and Wyszecki, 1975). Variance analysis of soil properties and cluster analysis by Ward's method in Euclidean space were carried out using Statistica software.

\section{Results and discussion}

Soils of the Herakleian Peninsula and modern structure of land

At present, and in particular over the last two decades, the rural territory of ancient Chersonesos has undergone considerable anthropogenic transformation (increased out-of-town dwelling construction, emergence of new summer-house blocks, expansion of recreation areas, military training, etc.).

The modern structure of land of the Herakleian Peninsula and its eastern surroundings (with a total area of 20,300 ha) is presented in Figure 3. Here three land types are predominant: residential/dwelling house blocks (27.5\%), out-of-town houses and non-built areas (20.4\% each). Agricultural fields and vineyards as well as light forests and shrubs make up $11 \%$ each, the smaller areas with an individual share of about $2-4 \%$ being occupied by orchards, out-of-town industrial areas, quarries and woodlands.

The high degree of anthropogenic transformation of these territories is clearly reflected in the fact that ecological land resources (the aggregate area of forage grounds and relict natural landscapes) account for only $33 \%$ of the total area, while one-fifth of the total area preserves open steppe terrain, of which only a small part is represented by post-antiquity long-fallow land within the divided rural territory of ancient Chersonesos.

As a result of clearing, woodlands have not survived near residential areas, although in both fallows and barrens the regrowth of shrubs, in particular junipers, can be observed. Thus, east of the 14th-15th century fortress of Cembalo, thin forests and shrubs constitute a $1.5 \mathrm{~km}$ wide buffer zone, and only further east does a sub-Mediterranean forest of Pinus stankewiczii (Sukacz.), Juniperus excelsa M.Bieb. and Pistacia atlantica Desf. (see Site 6, Table 1) begin to emerge. Thin growths of Juniperus excelsa M.Bieb. spread from Cape Fiolent to the Bay of Balaklava and define the specific characteristics of the Sevastopol district (Bondareva, 
Table I. Objects of study.

\begin{tabular}{|c|c|c|c|c|}
\hline Number in Figure I & $\begin{array}{l}\text { Coordinates } \\
\text { (WGS84) }\end{array}$ & Altitude (m) & $\begin{array}{l}\text { Object, anthropogenic } \\
\text { transformation of the soil }\end{array}$ & Plant association \\
\hline I & $44^{\circ} 36.83^{\prime} \mathrm{N} 29^{\circ} 40.67^{\prime} \mathrm{E}$ & 47 & $\begin{array}{l}\text { Earthen embankment of } 1905 \\
\text { artillery battery, soil aged } 100 \text { years }\end{array}$ & Graminae (Elytrigia repens, Avena fatua) \\
\hline 2 & $44^{\circ} 29.66^{\prime} \mathrm{N} 33^{\circ} 36.00^{\prime} \mathrm{E}$ & 99 & $\begin{array}{l}\text { Fortress of Cembalo, soil aged } 500 \\
\text { years }\end{array}$ & $\begin{array}{l}\text { Mixed herbs and grasses (Elytrigia repens, } \\
\text { Artemisia austriaca, Stipa capillata) }\end{array}$ \\
\hline 3 & $44^{\circ} 36.65^{\prime} \mathrm{N} 33^{\circ} 29.18^{\prime} \mathrm{E}$ & 35 & $\begin{array}{l}\text { Town site of Chersonesos, soil aged } \\
\text { c. } 700-800 \text { years }\end{array}$ & $\begin{array}{l}\text { Mixed herbs (Kochia prostrate, Artemisia } \\
\text { taurica, Delphinium consolida) }\end{array}$ \\
\hline 4 & $44^{\circ} 29.90^{\prime} \mathrm{N} 33^{\circ} 36.38^{\prime} \mathrm{E}$ & 139 & Steppe, Holocene & Wormwood and mixed herbs \\
\hline 5 & $44^{\circ} 29.83^{\prime} \mathrm{N} 33^{\circ} 36.49^{\prime} \mathrm{E}$ & 162 & Soil-forming rocks, Section 4 & - \\
\hline 6 & $44^{\circ} 29.12^{\prime} \mathrm{N} 33^{\circ} 37.55^{\prime} \mathrm{E}$ & 140 & $\begin{array}{l}\text { Forest, wildlife preserve of Cape } \\
\text { Aiya, Holocene }\end{array}$ & Pinus Stankewiczii, Juniperus excelsa \\
\hline 7 & $44^{\circ} 35.00^{\prime} \mathrm{N} 33^{\circ} 23.79^{\prime} \mathrm{E}$ & 8 & $\begin{array}{l}\text { Soil cultivated in antiquity (land } \\
\text { plot } 68 \text { ) }\end{array}$ & $\begin{array}{l}\text { Mixed herbs and grasses (Helichrysum } \\
\text { arenarium, Dianthus, Euphorbia seguierana, } \\
\text { Stipa capillata) }\end{array}$ \\
\hline 8 & $44^{\circ} 34.44^{\prime} \mathrm{N} 33^{\circ} 23.44^{\prime} \mathrm{E}$ & 10 & $\begin{array}{l}\text { Soil cultivated in antiquity (land } \\
\text { plot 62) }\end{array}$ & $\begin{array}{l}\text { Mixed herbs and grasses (Artemisia } \\
\text { austriaca, Eryngium campestre, Stipa } \\
\text { capillata,Avena fatua) }\end{array}$ \\
\hline 9 & $44^{\circ} 34.44^{\prime} \mathrm{N} 33^{\circ} 23.44^{\prime} \mathrm{E}$ & 10 & Soil-forming rocks, Section 8 & - \\
\hline 10 & $44^{\circ} 34.6 I^{\prime} \mathrm{N} 33^{\circ} 24.48^{\prime} \mathrm{E}$ & 9 & $\begin{array}{l}\text { Soil cultivated in antiquity (land } \\
\text { plot } 49 \text { ) }\end{array}$ & $\begin{array}{l}\text { Mixed herbs and grasses (Salvia austriaca, } \\
\text { Artemisia austriaca, Stipa capillata) }\end{array}$ \\
\hline 11 & $44^{\circ} 34.63^{\prime} \mathrm{N} 33^{\circ} 24.48^{\prime} \mathrm{E}$ & 9 & Soil-forming rocks, Section 10 & - \\
\hline 12 & $44^{\circ} 36.23^{\prime} \mathrm{N} 33^{\circ} 26.24^{\prime} \mathrm{E}$ & 19 & $\begin{array}{l}\text { Soil cultivated in antiquity (land } \\
\text { plot 3) }\end{array}$ & $\begin{array}{l}\text { Mixed herbs and grasses (Salvia austriaca, } \\
\text { Eryngium campestre, Stipa capillata) }\end{array}$ \\
\hline 13 & $44^{\circ} 30.33^{\prime} \mathrm{N} 33^{\circ} 29.80^{\prime} \mathrm{E}$ & 150 & $\begin{array}{l}\text { Soil cultivated in antiquity (land plot } \\
\text { 389) }\end{array}$ & $\begin{array}{l}\text { Mixed herbs and grasses (Phlomis tuberosa, } \\
\text { Eryngium campestre, Stipa capillata, Avena } \\
\text { fatua) }\end{array}$ \\
\hline 14 & $44^{\circ} 30.46^{\prime} \mathrm{N} 33^{\circ} 30.99^{\prime} \mathrm{E}$ & 250 & $\begin{array}{l}\text { Soil cultivated in antiquity (land plot } \\
387 \text { ) }\end{array}$ & $\begin{array}{l}\text { Mixed herbs and grasses (Festuca sulcata, } \\
\text { Eryngium campestre, Linum austriacum, } \\
\text { Plantago stepposa,Avena fatua) }\end{array}$ \\
\hline 15 & $44^{\circ} 29.72^{\prime} \mathrm{N} 33^{\circ} 36.63^{\prime} \mathrm{E}$ & 142 & Recently tilled land, fallowing regime & Wild oats (Avena fatua) \\
\hline
\end{tabular}

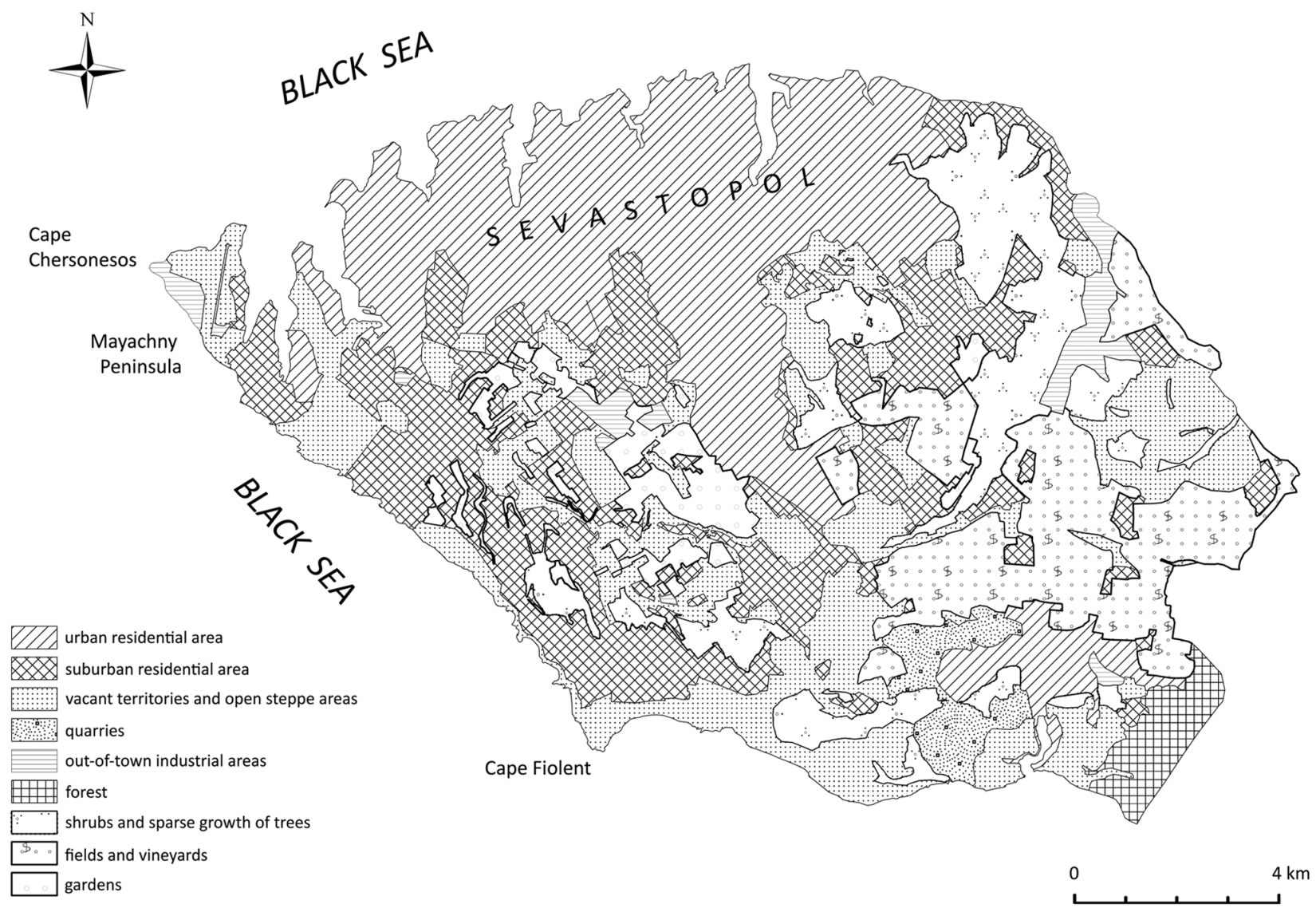

Figure 3. Main land types of Herakleian Peninsula discerned through satellite imagery. 
2005). The sparseness of forests facilitates the growth of steppe grasses, which is essential for the formation of cinnamonic soils.

As noted above (see also Figure 2), carbonated cinnamonic, light-clayey, gravelly soils with outcrops of dense carbonate rocks prevail in the area. In the southeastern section of the peninsula, the structure of the soil cover is more complex, with a broader extent of rendzinas on the eluvia of carbonate rocks.

The soils of the subtropical zone of dry forests - the cinnamonic forest soils - were first described by SA Zacharov (1929). Gerasimov (1949) considered the cinnamonic soils of dry subtropical forests and shrubberies a distinct soil type. In the genetic ecological-substantive classification of Ukrainian soils, where soils modified by cultivation are distinguished at a taxonomic level, these are referred to as cinnamonic soils with a low ability to accumulate humus (Polupan et al., 2005). According to the FAO soil classification system, arable and long-fallow soils in the area of study, including turbated soils in the areas of viti- and horticulture, can be assigned to Anthrosols. The new Russian classification, which draws on substantive soil features (Polevoj opredelitel', 2008) assigns the soils under study to three groups: group of structure-metamorphic soils (cinnamonic and agro-cinnamonic types), the group of turbozems (calcic post-agrogenic turbozems) and the group of lithozems (dark post-agrogenic carbolithozems).

The mountain cinnamonic soils are formed on a great variety of rocks: limestones, marls, sandstones, conglomerates and schists, as well as their clayey detritus eluvia and mixed deluvia (Počvy, 1969). On the Mayachny Peninsula, reddish limestones are bedded close to the surface, as are grey limestones on the eastern shore of the Solyonaya Bay at a depth of c. 60-70 cm (see sections 9 and 11 in Table 1).

On the main ridge of the Crimean Mountains, the products of weathered Upper-Jurassic limestones acquire a reddish hue. Thus the lower horizons of cinnamonic soil on the limestone blocks of the fortress of Charax (12 km west of Yalta; aged $c$. 1600-1700 yr) are dark greyish-brown (10 YR 4/2) and dark reddish-brown (5 YR 3/3). On Cape Chersonesos, the limestones are stratified with thin clayey intercalations which, when dry, are dark red (10 R 3/6) and contain $9.4 \%$ of $\mathrm{Fe}$ and $19.7 \%$ of $\mathrm{Al}$ oxides.
Owing to the red-coloured products of limestone weathering, the cinnamonic (calfersic) soils on carbonate rocks stand apart as a distinctive soil type. As argued by Kočkin (1967), there are no grounds to regard the Crimean mountain cinnamonic soils as relict soils. They are modern soils, and their humus horizon retains the colour of the soil-forming rocks. Recently recovered palaeoenvironmental data (Cordova and Lehman, 2005) suggest, however, that around $3 \mathrm{ka} \mathrm{BP}$, new hot and moist climatic conditions correspond already to rendzinas and chernozems rather than the cinnamonic soils of the preceding period.

In the profile of modern soils at Cape Fiolent, an upper horizon of meadow rendzina up to $20 \mathrm{~cm}$ thick can be distinguished, overlaying a horizon of calcic cinnamonic soil, which itself rests at a depth of $115 \mathrm{~cm}$ on a palaeo-surface dated by ${ }^{14} \mathrm{C}$ to $c .4 \mathrm{ka} \mathrm{BP}$ (Cordova and Lehman, 2005).

\section{Transformation of physico-chemical properties in cinnamonic-soil humus horizons by natural processes}

The chemical analyses in Tables 2 to 4 reveal that as many as 40 (not equally informative) indicators can be used to identify trends in changes in properties of the cinnamonic soils over time. Collated average late-Holocene formation rates in the main Crimean soil types have demonstrated that the cinnamonic soils stand out for their low formation rates and in that respect close the following descending sequence: (1) southern chernozems and dark-chestnut soils; (2) brown forest soils; and (3) cinnamonic gravelly soils (Lisetskii and Ergina, 2010). The model designed for parent material deposits such as carbonated eluvium and describing the dependence of the humus horizon $(H, \mathrm{~mm})$ on time $(t, \mathrm{yr})$ (Figure 4$)$ has the form:

$$
H=400 \cdot \exp [-\exp (0.217-0.00048 \cdot t)] ; r=0.825
$$

According to this model, the average humus horizon formation rate for cinnamonic gravelly soils during the first $2 \mathrm{ka}$ of pedogenesis was estimated at $6.9 \mathrm{~mm} / 100 \mathrm{yr}$, or about $0.88 \mathrm{t} / \mathrm{ha}$ annually. In the initial period of soil formation, the average humus horizon accumulation rate for cinnamonic gravelly soils drops sharply from 9 to $5 \mathrm{~mm} / 100 \mathrm{yr}$, gradually stabilizing at 3.5 $\mathrm{mm} / 100 \mathrm{yr}$ after $800 \mathrm{yr}$.

Table 2. Physico-chemical properties of soils of Herakleian peninsula.

\begin{tabular}{|c|c|c|c|c|c|c|c|c|c|c|c|}
\hline \multirow[t]{2}{*}{ Sample no. } & \multirow[t]{2}{*}{$\begin{array}{l}\text { Munsell colour } \\
\text { (dry soil) }\end{array}$} & \multirow[t]{2}{*}{$\begin{array}{l}\mathrm{VW}^{\mathrm{a}} \\
\left(\mathrm{g} / \mathrm{cm}^{3)}\right.\end{array}$} & \multirow[t]{2}{*}{$W^{b}$} & \multicolumn{2}{|c|}{ Contents (\%) } & \multirow[t]{2}{*}{$\mathrm{pH} \mathrm{H} \mathrm{H}_{2} \mathrm{O}$} & \multirow[t]{2}{*}{$\begin{array}{l}\mathrm{P}_{2} \mathrm{O}_{5} \\
(\mathrm{mg} / \mathrm{kg})\end{array}$} & \multicolumn{4}{|c|}{$\begin{array}{l}\text { Adsorbed bases } \\
\left(\mathrm{mmol} / \mathrm{dm}^{3} \text { per } 100 \mathrm{~g}\right)\end{array}$} \\
\hline & & & & $\mathrm{CaCO}_{3}$ & humus & & & $\mathrm{Ca}^{2+}$ & $\mathrm{Mg}^{2+}$ & $\mathrm{Na}^{+}$ & Total \\
\hline I & I0YR 6/I & 0.68 & 83 & 46.88 & 8.50 & 7.9 & 500.0 & 19.0 & 4.4 & 0.1 & 25.8 \\
\hline 2 & IOYR 5/3.5 & 1.07 & 85 & 24.16 & 4.12 & 7.9 & 78.0 & 18.4 & 0.6 & 0.1 & 20.4 \\
\hline 3 & I0YR 6/2 & 0.84 & 94 & 44.86 & 7.00 & 7.9 & 220.0 & 20.4 & 1.6 & 0.1 & 24.7 \\
\hline 4 & 7.5YR 5/6 & 0.92 & 91 & 10.87 & 7.00 & 7.8 & 27.7 & 26.6 & 1.0 & 0.1 & 28.3 \\
\hline 5 & I0YR $6 / 6$ & - & 90 & 30.31 & 2.83 & 7.8 & 7.9 & 21.6 & 5.2 & 0.1 & 27.2 \\
\hline 6 & I0YR 6/2.5 & 0.87 & 95 & 6.86 & 9.57 & 7.5 & 22.0 & 26.6 & 3.2 & 0.1 & 30.7 \\
\hline 7 & 7.5 YR 5/7 & 1.20 & 89 & 46.88 & 5.40 & 7.9 & 20.6 & 19.6 & 1.6 & 0.1 & 22.8 \\
\hline 8 & 5 YR 5/6 & 1.24 & 93 & 49.30 & 4.27 & 7.9 & 15.4 & 17.0 & 1.6 & 0.1 & 19.7 \\
\hline 9 & $5 Y R 6 / 8$ & - & 21 & 53.30 & 1.02 & 7.9 & 8.1 & - & - & - & - \\
\hline 10 & I0YR 6/4 & 0.91 & 91 & 48.09 & 5.22 & 7.9 & 14.2 & 21.6 & 1.8 & 0.1 & 24.6 \\
\hline 11 & IOYR 7/2 & - & 56 & 63.85 & 1.40 & 7.8 & 10.6 & 10.4 & 9.4 & 9.0 & 30.4 \\
\hline 12 & I0YR 5/6 & 0.92 & 79 & 52.94 & 4.50 & 7.9 & 12.2 & 16.8 & 2.4 & 0.1 & 20.5 \\
\hline 13 & IOYR 5/4 & 1.04 & 88 & 23.03 & 4.22 & 7.8 & 9.8 & 29.2 & 1.6 & 0.1 & 32.2 \\
\hline 14 & 7.5 YR $3 / 4$ & 0.93 & 74 & 7.27 & 5.55 & 7.8 & 8.5 & 38.8 & 1.6 & 0.1 & 41.3 \\
\hline 15 & IOYR 6/4 & 1.08 & 78 & 8.08 & 2.30 & 7.9 & 34.1 & 19.6 & 1.8 & 0.1 & 22.6 \\
\hline
\end{tabular}

Notes:

aVW: volume weight.

bW: ratio of water-resistance according to PI Andrianov (Dospechov et al., 1987). 
Table 3. Humus conditions of agrogenically modified soils of different age and corresponding parent rocks.

\begin{tabular}{|c|c|c|c|c|c|c|c|c|c|c|c|c|c|c|}
\hline \multirow{2}{*}{$\begin{array}{l}\text { Sample } \\
\text { number }\end{array}$} & \multirow[t]{2}{*}{$C(-\%)$} & \multirow{2}{*}{$\begin{array}{l}\text { Nitrogen } \\
\text { total (\%) }\end{array}$} & \multirow[t]{2}{*}{$\mathrm{C} / \mathrm{N}$} & \multicolumn{4}{|l|}{$\mathrm{HA}$} & \multicolumn{5}{|l|}{ FA } & \multirow[t]{2}{*}{ Humin } & \multirow[t]{2}{*}{$\mathrm{C}_{\mathrm{HA}} / \mathrm{C}_{\mathrm{FA}}$} \\
\hline & & & & I & 2 & 3 & $\Sigma$ & la & I & 2 & 3 & $\Sigma$ & & \\
\hline I & 4.94 & 0.472 & 10 & 0.9 & 1.9 & 7.3 & 10.1 & 1.4 & 1.0 & 2.4 & 10.8 & 15.7 & 74.2 & 0.65 \\
\hline 2 & 2.75 & 0.270 & 10 & 0.7 & 1.4 & 2.0 & 4.1 & 1.6 & 1.0 & 0.0 & 9.2 & 11.8 & 84.1 & 0.35 \\
\hline 3 & 4.22 & 0.416 & 10 & 0.5 & 2.8 & 7.0 & 10.4 & 2.4 & 0.1 & 2.6 & 11.3 & 16.4 & 73.2 & 0.63 \\
\hline 4 & 3.58 & 0.416 & 9 & 0.2 & 1.6 & 6.4 & 8.2 & 2.5 & 0.4 & 3.8 & 12.8 & 19.5 & 72.3 & 0.42 \\
\hline 5 & 1.66 & 0.203 & 8 & 0.1 & 0.8 & 0.3 & 1.2 & 1.9 & 0.1 & 1.4 & 11.8 & 15.1 & 83.7 & 0.08 \\
\hline 6 & 5.73 & 0.406 & 14 & 0.3 & 3.7 & 8.7 & 12.7 & 2.0 & 0.4 & 4.6 & 10.4 & 17.4 & 69.9 & 0.73 \\
\hline 7 & 2.71 & 0.262 & 10 & 0.2 & 0.9 & 6.3 & 7.4 & 2.1 & 0.8 & 0.3 & 9.7 & 12.9 & 79.7 & 0.57 \\
\hline 8 & 2.26 & 0.207 & II & 0.3 & 1.8 & 3.0 & 5.1 & 1.9 & 0.1 & 0.4 & 12.0 & 14.4 & 80.6 & 0.35 \\
\hline 9 & 1.02 & 0.080 & 13 & I.I & 0.5 & 3.0 & 4.6 & 5.4 & 7.6 & 0.0 & 8.9 & 22.0 & 73.5 & 0.21 \\
\hline 10 & 2.83 & 0.287 & 10 & 0.1 & 1.7 & 3.1 & 5.0 & 2.1 & 0.0 & 0.4 & 9.7 & 12.2 & 82.8 & 0.40 \\
\hline II & 1.47 & 0.157 & 9 & 0.8 & 2.1 & 4.6 & 7.5 & 4.8 & 2.9 & 0.0 & 12.1 & 19.8 & 72.7 & 0.38 \\
\hline 12 & 2.45 & 0.228 & II & 0.6 & 2.2 & 3.3 & 6.1 & 2.1 & 0.8 & 0.0 & 10.8 & 13.7 & 80.2 & 0.44 \\
\hline 13 & 2.34 & 0.196 & 12 & 0.4 & 2.1 & 1.3 & 3.8 & 2.8 & 0.3 & 0.3 & 10.9 & 14.2 & 82.0 & 0.27 \\
\hline 14 & 3.39 & 0.319 & II & 0.1 & 2.7 & 7.5 & 10.2 & 1.5 & 0.9 & 1.8 & 15.9 & 20.1 & 69.6 & $0.5 I$ \\
\hline 15 & 1.28 & 0.130 & 10 & 0.7 & 2.5 & 7.3 & 10.4 & 2.4 & 0.7 & 0.0 & 8.1 & 9.2 & 80.4 & 1.13 \\
\hline Charax Ia & 7.47 & 0.616 & 12 & 1.7 & 3.8 & 11.6 & I7.I & 4.7 & 0.4 & 2.8 & 11.7 & 19.6 & 63.3 & 0.87 \\
\hline Charax $2^{\mathrm{b}}$ & 10.56 & 0.822 & 13 & 0.7 & 3.5 & 9.3 & 13.5 & 4.2 & 3.3 & 12.5 & 7.1 & 27.0 & 59.5 & 0.50 \\
\hline
\end{tabular}

Notes:

${ }^{a}$ Rendzina on clay.

${ }^{b}$ Cinnamonic gravelly soil on walls of the Roman fortress of Charax (S coast of Crimea), aged I600-I700 yr (Lisetskii and Ergina, 20I0).

Table 4. Bulk chemical composition of soils of Herakleian Peninsula and some equivalents.

\begin{tabular}{|c|c|c|c|c|c|c|c|c|c|c|c|c|c|c|c|c|c|c|c|c|}
\hline \multirow{2}{*}{$\begin{array}{l}\text { Number in } \\
\text { Table I }\end{array}$} & \multicolumn{16}{|c|}{ Contents of macro- and microelements (\%) } & \multicolumn{4}{|c|}{ Geochemical indicators $^{\mathrm{b}}$} \\
\hline & $\mathrm{SiO}_{2}$ & $\mathrm{Fe}_{2} \mathrm{O}_{3}$ & $\mathrm{Al}_{2} \mathrm{O}_{3}$ & $\mathrm{CaO}$ & $\mathrm{MgO}$ & $\mathrm{Na}_{2} \mathrm{O}$ & $\mathrm{K}_{2} \mathrm{O}$ & $\mathrm{MnO}$ & $\mathrm{P}_{2} \mathrm{O}_{5}$ & $\mathrm{TiO}_{2}$ & v & $\mathrm{Zn}$ & $\mathrm{Cr}$ & $\mathrm{Ni}$ & $\mathrm{Rb}$ & $\mathrm{Sr}$ & $\begin{array}{l}\mathrm{SiO}_{2} / \\
\left(10 \cdot \mathrm{R}_{2} \mathrm{O}_{3}\right)\end{array}$ & $C_{\mathrm{e}}$ & G & $\mathrm{R}$ \\
\hline I & 26.31 & 2.60 & 7.74 & 31.91 & 6.29 & 3.78 & 1.60 & 0.08 & 2.11 & 0.32 & 0.004 & 0.017 & 0.005 & 0.005 & 0.005 & 0.033 & 0.25 & 0.60 & 26.89 & - \\
\hline 2 & 46.01 & 4.36 & 9.93 & 10.52 & 2.62 & 1.48 & 1.98 & 0.07 & 0.55 & 0.57 & 0.009 & 0.012 & 0.007 & 0.006 & 0.009 & 0.013 & 0.32 & 2.76 & 23.05 & - \\
\hline 3 & 32.63 & 3.11 & 8.37 & 25.02 & 5.11 & 2.66 & 1.90 & 0.08 & 1.24 & 0.39 & 0.006 & 0.018 & 0.006 & 0.005 & 0.007 & 0.026 & 0.28 & 0.94 & 24.75 & - \\
\hline 4 & 50.87 & 6.33 & 11.61 & 5.77 & 1.83 & 3.29 & 1.86 & 0.20 & 0.46 & 0.68 & 0.010 & 0.014 & 0.008 & 0.009 & 0.006 & 0.009 & 0.28 & 3.93 & 24.64 & 1.35 \\
\hline 5 & 39.46 & 4.33 & 10.78 & 16.61 & 3.56 & 1.93 & 1.37 & 0.09 & 0.17 & 0.55 & 0.009 & 0.009 & 0.007 & 0.007 & 0.008 & 0.008 & 0.26 & 1.67 & 22.15 & - \\
\hline 6 & 53.58 & 5.37 & 14.68 & 5.15 & 1.92 & 2.02 & 2.50 & 0.07 & 0.17 & 0.73 & 0.012 & 0.011 & 0.009 & 0.007 & 0.012 & 0.027 & 0.27 & 4.60 & 24.64 & - \\
\hline 7 & 31.59 & 3.29 & 10.55 & 26.07 & 5.00 & 3.68 & 1.42 & 0.06 & 0.21 & 0.45 & 0.007 & 0.011 & 0.007 & 0.006 & 0.006 & 0.015 & 0.23 & 0.87 & 23.30 & 1.25 \\
\hline 8 & 44.77 & 4.22 & 9.73 & 11.30 & 2.57 & 2.26 & 1.14 & 0.05 & 0.16 & 0.56 & 0.008 & 0.008 & 0.007 & 0.006 & 0.007 & 0.009 & 0.32 & 2.58 & 21.98 & 1.25 \\
\hline 9 & 27.11 & 2.56 & 7.78 & 27.46 & 5.39 & 3.79 & 1.20 & 0.04 & 0.15 & 0.33 & 0.005 & 0.007 & 0.006 & 0.005 & 0.006 & 0.021 & 0.26 & 0.72 & 21.53 & - \\
\hline 10 & 32.78 & 3.59 & 10.37 & 24.76 & 5.23 & 2.26 & 2.02 & 0.08 & 0.24 & 0.49 & 0.007 & 0.009 & 0.006 & 0.006 & 0.007 & 0.017 & 0.23 & 0.95 & 23.00 & 1.34 \\
\hline 11 & 28.87 & 2.55 & 7.06 & 26.93 & 5.79 & 3.32 & 1.56 & 0.05 & 0.21 & 0.37 & 0.005 & 0.006 & 0.006 & 0.005 & 0.006 & 0.023 & 0.30 & 0.77 & 21.92 & - \\
\hline 12 & 32.18 & 3.22 & 8.59 & 23.20 & 4.56 & 3.00 & 1.55 & 0.05 & 0.19 & 0.41 & 0.007 & 0.012 & 0.006 & 0.006 & 0.006 & 0.036 & 0.27 & 0.99 & 21.93 & - \\
\hline 13 & 41.84 & 4.50 & 9.67 & 13.60 & 3.02 & 1.83 & 1.44 & 0.07 & 0.17 & 0.53 & 0.009 & 0.010 & 0.008 & 0.006 & 0.007 & 0.022 & 0.30 & 2.10 & 21.78 & - \\
\hline 14 & 51.49 & 5.79 & 10.76 & 4.01 & 1.48 & 1.67 & 1.34 & 0.09 & 0.14 & 0.65 & 0.010 & 0.008 & 0.010 & 0.007 & 0.008 & 0.008 & 0.31 & 5.99 & 22.17 & - \\
\hline 15 & 52.52 & 5.66 & 12.08 & 4.16 & 1.49 & 1.69 & 2.22 & 0.13 & 0.18 & 0.64 & 0.011 & 0.010 & 0.008 & 0.007 & 0.010 & 0.014 & 0.30 & 5.42 & 23.30 & - \\
\hline $\begin{array}{l}\text { Clay (Cape } \\
\text { Chersonesos) }\end{array}$ & 44.48 & 9.39 & 19.73 & 0.71 & 1.37 & 0.32 & 1.56 & 0.05 & 0.11 & 0.59 & 0.011 & 0.016 & 0.014 & 0.012 & 0.016 & 0.007 & 0.15 & 11.09 & 20.73 & - \\
\hline Charax I & 36.16 & 3.23 & 8.75 & 20.50 & 4.29 & 2.32 & 1.59 & 0.06 & 0.61 & 0.49 & 0.007 & 0.018 & 0.007 & 0.005 & 0.007 & 0.017 & 0.30 & 1.26 & 22.94 & - \\
\hline Charax 2 & 48.42 & 5.44 & 10.11 & 5.54 & 1.75 & 0.33 & 1.91 & 0.09 & 0.30 & 0.63 & 0.010 & 0.015 & 0.009 & 0.007 & 0.012 & 0.011 & 0.31 & 5.03 & 21.42 & - \\
\hline Martyan ${ }^{\mathrm{a}}$ & 63.80 & 8.30 & 19.00 & 2.90 & 1.10 & - & 1.90 & 0.10 & - & - & - & - & - & - & - & - & 0.43 & 9.97 & - & - \\
\hline
\end{tabular}

Notes:

aRed cinnamonic soil on limestone hillwash, horizon A (3-12 cm). National park 'Mys Martyan' (Atlas, 1979).

${ }^{\mathrm{b}} \mathrm{C}_{\mathrm{e}}$ : eluviation coefficient; G: Gibbs free energy, $\mathrm{kJ} / \mathrm{I} 00 \mathrm{~g}$; R: microelement accumulation capability; -: data absent.

However, evaluation of the rates of pedogenesis through weathering of carbonated bedrock based on the Liu et al. (2009) method - collating concentrations of calcium carbonate and oxides of $\mathrm{Fe}, \mathrm{Ti}, \mathrm{Mg}, \mathrm{K}, \mathrm{Ca}$ and $\mathrm{Na}$ (aluminium being chosen as a reference element) - indicates that, in contrast to the first $500 \mathrm{yr}$ of soil accumulation, in the subsequent period, up to $10 \mathrm{ka}$, the process rate is slowed down by $10 \%$.
Within the city walls of ancient Chersonesos (Sections 1 and 3 ), soils have inherited a series of characteristics from the cultural layers, which makes their characteristics' dependence on time not straightforward. In a chronological sequence of soils aged from 500 to 11,500 (according to Cordova and Lehman, 2005) yr (Sections $2-4,6$, Table 2), the amount of humus in the upper horizon increases from $4.1 \%$ to $7.0 \%$ under steppe vegetation and up to 


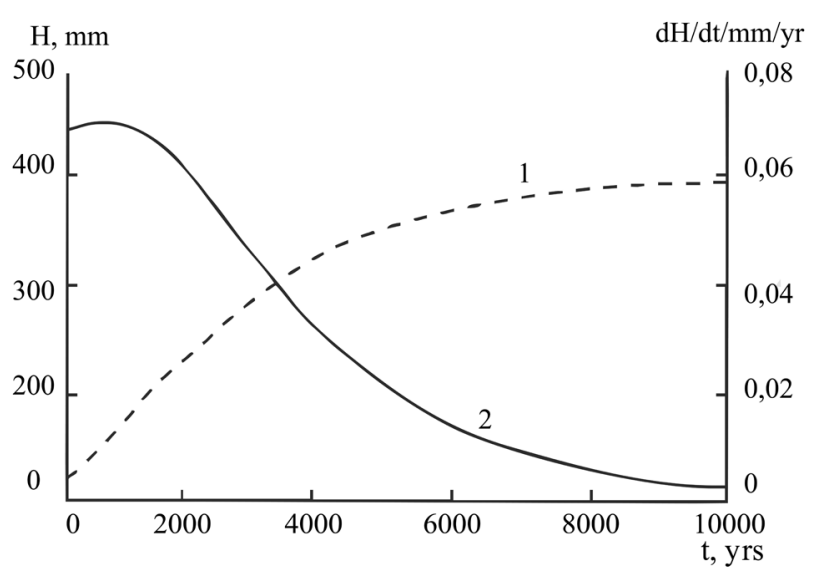

Figure 4. Changes in humus horizon thickness $(H(I))$ and formation rate $(\mathrm{d} H / \mathrm{d} t(2))$ in Crimean cinnamonic soils over time.

9.6\% under sub-Mediterranean forest. Assuming a logarithmic dependence on time for humus accumulation in the upper horizon of the Crimean cinnamonic soils, we arrive at an estimated average rate of $0.037 \% / 100 \mathrm{yr}$.

With age, soils become richer in nitrogen; but the full-Holocene soils retain differences determined by vegetation type: $\mathrm{C}: \mathrm{N}$ $=13$ for soils under steppe, and 21 for soils under forest cenoses. In both full-Holocene soils and those of differing ages, the type of humus occurring is fulvic or humate fulvic, with no dependence on soil age being observed. However, differences in soil age are distinctly exhibited in the fractional composition of humus: in more mature soils, the percentage of labile fractions decreases (HA I, FA I). The primary carbonate content of the upper horizon of the cinnamonic soils has decreased almost thrice during the Holocene period; the percentage of calcium in the soil absorption complex has increased (see Table 2). The weight of the HA II fraction, which relates to calcium and largely determines the effectiveness of structural formation, naturally grows with age and already after $1.6 \mathrm{ka}$ reaches the zonal values characteristic of soil-forming conditions under sub-Mediterranean forests (see Table 3).

In the chronological sequence of soils, the increase in the proportion of silica, the amount of which in the accumulative horizon of the full-Holocene soils varies from 51\% (under steppe) to $54 \%$ (under forest), is particularly indicative. It is natural therefore that the eluviation coefficient increases with soil age (up to 4-5), reaching 10 in the horizon $\mathrm{A}_{\mathrm{Ca}}(3-12 \mathrm{~cm})$ of the red-cinnamonic soil under the climatic conditions of the southern coast of Crimea (see Table 4). With age, the accumulation in soil of both $\mathrm{SiO}_{2}$ and metal sesquioxides accelerates. In the full-Holocene soils, the ratio $\mathrm{SiO}_{2} /\left(10 \cdot \mathrm{R}_{2} \mathrm{O}_{3}\right)$ stabilizes at a level of $0.27-0.28$.

In the early formation stages of cinnamonic soils $(0.5-1 \mathrm{ka})$, when enrichment of the upper soil horizon with such elements as $\mathrm{P}, \mathrm{Sr}$ and $\mathrm{Zn}$ was just beginning, this horizon can be regarded as a diagnostic horizon of carbolithozems. The cinnamonic fullHolocene soils (regardless of vegetation type) are enriched in $\mathrm{Fe}$, $\mathrm{Ti}$ and $\mathrm{Si}$. Additionally, the soils under steppe accumulate more $\mathrm{Mn}, \mathrm{Na}$ and $\mathrm{Ni}$, while those under forest are richer in $\mathrm{Rb}, \mathrm{Al}, \mathrm{V}$ and $\mathrm{Cr}$.

According to thermodynamic notions, soil formation is a process of regular increases in the thermodynamic and energetic parameters of the substratum on which the soils form. With age, Gibbs free energy is amplified, hence the dissolution of energy involved in the pedogenetic processes rises, including the energy directed to enhance the system's state of order. In the cinnamonic soils of Crimea, their Gibbs free energy increases from $222 \mathrm{~J} /$ $(\mathrm{kg} \cdot \mathrm{K})$ in the parental rock (limestones) to $246 \mathrm{~J} / /(\mathrm{kg} \cdot \mathrm{K})$ in the full-Holocene soils.

\section{Features of post-agrogenic soils}

Specific features of post-agrogenic evolution manifest themselves in significantly different reproduction rates of ecosystems, depending on the natural zones and the level of agrogenic stress to which soils and plants have been exposed (Ljuri et al., 2010). In present-day conditions, soils of the dry-steppe zone (dark-chestnut soils, often in combination with steppe solonetzes) are subjected to deep or plantage ploughing, including for vines, to a depth of at least $0.6-0.7 \mathrm{~m}$. On the Herakleian Peninsula, the 0.3-0.4 m thick layer of soil is underlain by an almost equally thick layer of Sarmatian series limestones which the Greek farmers attempted to destroy. For this reason, disturbance from ancient cultivation is recorded at a depth of 0.5-0.8 m (Strželeckij, 1961: 69). Our soil sections on the eastern shore of the Solyonaya Bay indicate that, despite the closeness of limestones, ancient plantage ploughing for vines and orchards was as deep as $0.6 \mathrm{~m}$. In the soils retaining the complete profile, the metamorphic carbonated clayey horizon lies at the depth of $0.5-0.8 \mathrm{~m}$ and has a heavier granulometric composition and more intense brown or reddish-brown colour than the humus-accumulative horizon. Thus the disturbances caused by planting activities occurred in the humus horizon as well as the upper and lower transitional horizons of the cinnamonic soils. The lower transitional horizon is the thickest, and the contribution of its specific properties (brown or dark brown-reddish with a chocolate hue, cloddy, gravelly, cartilaginous, carbonated (Polupan et al., 2005)) was very significant.

During dry periods of the year, the iron oxides evolved by weathering dehydrate, and form films on the surface of the soil particles, rendering a bright brown colouration throughout the claying horizons. This colour is diagnostic of the process of redweathering or rubification (Bagrova et al., 2003). The transformation of iron compounds into red hematite soil pigment is determined by the specifics of soil conditions: high average annual temperatures, pronounced dry and wet periods of the year, scanty amounts of humus and, particularly, its water-soluble substances (Elementarnye, 1999). Visually, the signs of rubification can be diagnosed by the change in intensity of red hues from 7.5 YR 5/6-5/8 to $10 \mathrm{R} 3 / 6$ (in numerical codes, from 17.5 to 20: Judd and Wyszecki, 1975: 426).

Compared with the parent rocks, and as an effect of increase in the amount of humus (by 4.2 absolute \%) and iron oxides (by $150-160 \%$ ), the coloration of the upper horizon of post-agrogenic soils on red rocks on Cape Chersonesos has altered, having lost brightness and hues by one grade of the Munsell scale (see Tables 2 and 4). In soils formed on the light-grey calcareous parent materials, the colour of the ploughed horizon changes towards a lesser brightness (by one grade) and a more enhanced hue (by two grades), the causes being the same: the accumulation of humus (to $3.8 \%$ ) and increased content of $\mathrm{Fe}$ (1.4 times) and $\mathrm{Al}$ oxides.

In the post-agrogenic long-fallow regime, natural restoration of certain soil properties takes place. Using a model built on the data in Figure 4, it has been calculated that over $500 \mathrm{yr}$ of fallowing, the recent soil formation can affect most actively a horizon of $14-17 \mathrm{~cm}$ thickness.

Low lability of soil phosphorus compared with other nutritious components, and small reversibility of the biological accumulation of phosphates in the upper soil horizons account for its suitability as a marker of natural evolution and agrogenic impacts. Studies of agricultural terraces cultivated for over 1500 years in Peru (Sandor and Eash, 1995) showed that in horizon A (0-15 $\mathrm{cm}$ ), long-fallow soils contained the largest amount of phosphorus $(1313 \mathrm{mg} / \mathrm{kg})$, whereas in currently cultivated soils and virgin soils these values appear to be smaller: 910 and $773 \mathrm{mg} / \mathrm{kg}$, respectively. These differences are also evident in the comparative values of the labile phosphorus (44 versus 15 and $12 \mathrm{mg} / \mathrm{kg}$, respectively). 
Mass analyses (Kočkin et al., 1972; Počvy, 1969) demonstrated that the Crimean cinnamonic soils contain a small quantity of labile phosphorus (less than $10 \mathrm{mg} / \mathrm{kg}$ ), whereas the bulk phosphorus throughout the profile $(0-50 \mathrm{~cm})$ amounts to $0.09-$ $0.17 \%$. Our data (Table 2) also confirm that in the upper horizon of the undisturbed cinnamonic soils, both under steppe vegetation (Section 4) and under sub-Mediterranean forest (Section 6), the quantity of labile phosphates is equally small $(8 \mathrm{mg} / \mathrm{kg})$. The soils formed on cultural layers of archaeological sites inherit a large amount of phosphorus (see Sections 1-3). In the postagrogenic cinnamonic soils, the average active phosphates content comes to $13 \mathrm{mg} / \mathrm{kg}$ (ranging from 9 to $21 \mathrm{mg} / \mathrm{kg}$ ), while in the agro-cinnamonic soil of the current long-fallow area, which at $800 \mathrm{~m}$ distance from the fortress of Cembalo today may during the mid-14th and 15th centuries has been within the zone of agricultural activity, it increases to $34 \mathrm{mg} / \mathrm{kg}$. Thus one may assume that after deep ploughing, the upper horizon of carbonated turbozems contained no more than $0.11-0.13 \%$ of bulk phosphorus and $8-9 \mathrm{mg} / \mathrm{kg}$ of the labile phosphates. Only later on, as an effect both of Greek farming and, primarily, of the bio-geochemical processes stimulated by decomposition of the steppe vegetation in the long-fallow regime (over $500 \mathrm{yr}$ ), the content of bulk phosphorus increased on average by 54 relative \%, while its labile forms accrued from 34 to $90 \%$.

Often conditions of pedogenesis, rather than parent rocks, determine the content of microelements in soils (Oertel, 1961). The agrogenic and post-agrogenic transformations of the soils of the Herakleian Peninsula over the last 2.5 ka exhibit a close relationship between the processes of weathering and soil formation. Since local soils do not freeze through, intensive weathering of the primary and formation of the secondary clayey minerals of a hydromica-montmorillonite-illite composition occur over the entire wet, relatively warm winter period.

As is generally known (Ukazanija, 1967), the relatively narrow molar ratio $\mathrm{SiO}_{2} / \mathrm{R}_{2} \mathrm{O}_{3}(4-5)$ is among the characteristic features of the cinnamonic soils as a soil type. The data in Table 4 demonstrate that agrogenesis, compared with parent rocks, increases the proportion of both sesquioxides and silica (by 110$160 \%$ ), the increase rate of denominator exceeding that of numerator in the molar ratio $\mathrm{SiO}_{2} / \mathrm{R}_{2} \mathrm{O}_{3}$. In the post-agrogenic soils, owing to farming and the subsequent long-fallow regime, the extent of intra-soil weathering of minerals reaches the maturity level of $64 \%$ (ranging from $54 \%$ to $74 \%$ ), compared with the fullage model sample (soil on Cape Martyan).

Along with the modified indicator $\mathrm{SiO}_{2} /\left(10 \cdot \mathrm{R}_{2} \mathrm{O}_{3}\right)$, we have calculated the eluviation coefficient $\left(C_{\mathrm{e}}\right)$ in soils and parent rocks (Table 4), which is determined by the formula: $C_{\mathrm{e}}=\mathrm{SiO}_{2} /$ $\left(\mathrm{RO}+\mathrm{R}_{2} \mathrm{O}\right)$ (Liu et al., 2009). For local soils, such an extension is justified, allowing the diagnosis not only of the accumulation of iron and aluminium oxides in the finely dispersed granulometric fractions, but also of mineral salts, including those introduced aerially from the Black Sea.

The coefficients of accumulation of microelements in the upper horizon of the long-fallow soils range from 1.25 to 1.34 (Table 4). In terms of the order of accumulation of the elements they are expressed as (1) for soils on the light-coloured calcareous parent materials: $\mathrm{Mn}>\mathrm{Zn}>\mathrm{Cu}>\mathrm{Ti}>\mathrm{Ni}>\mathrm{Cr}>\mathrm{V}$ (the fullHolocene soil under steppe) and $\mathrm{Mn}>\mathrm{Zn}>\mathrm{Cu}>\mathrm{V}>\mathrm{Ti}>\mathrm{Ni}>$ $\mathrm{Cr}$ (post-agrogenic soil); (2) for soils on the red-coloured calcareous parent materials: $\mathrm{Ti}>\mathrm{V}>\mathrm{Mn}>\mathrm{Cr}>\mathrm{Zn}>\mathrm{Ni}$ and $\mathrm{Zn}>\mathrm{Mn}>$ $\mathrm{V}>\mathrm{Ti}>\mathrm{Cr}>\mathrm{Ni}$ (post-agrogenic soils in both cases). Thus the highest accumulation of microelements in the post-agrogenic soils, compared with the original soil-forming rocks, has been determined for Ti, V, Mn and $\mathrm{Zn}$ (in order of significance).

Analysis of statistically significant indicators allows identification of a series of soil characteristics that diagnose the agrogenic transformations most reliably: labile phosphorus, coefficient

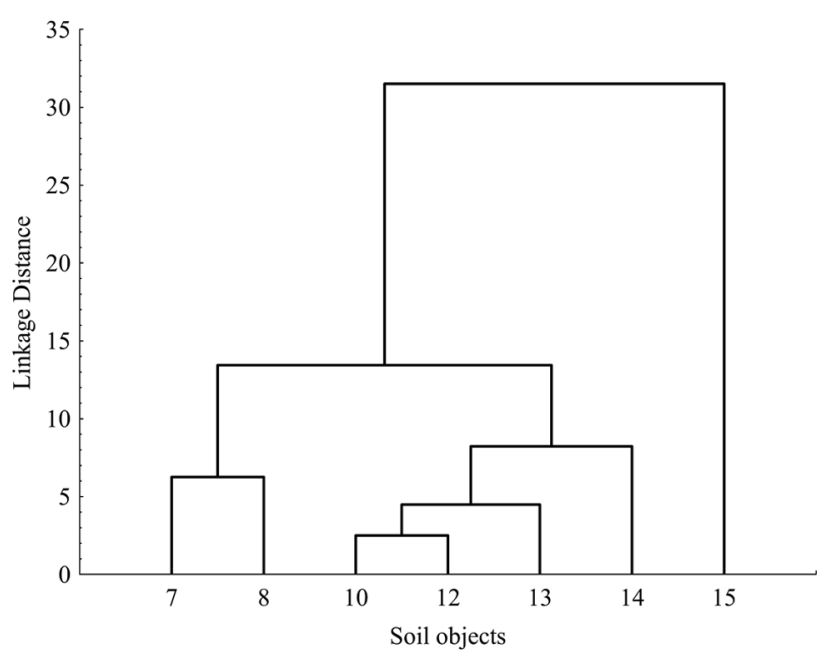

Figure 5. Cluster analysis results for long-fallow soils of Herakleian Peninsula.

of eluviation, acidity, organic carbon, $\mathrm{C} / \mathrm{N}, \mathrm{Cha} / \mathrm{Cfa}$, Gibbs energy, density of formation, the effectiveness of humus in the water-resistance of the structure $(\mathrm{W} / \mathrm{H})$, and $\mathrm{SiO}_{2} /\left(10 \mathrm{R}_{2} \mathrm{O}_{3}\right)$. To this series has also been added a genetic characteristic: the hue of soil colour. Cluster analysis of soils cultivated in antiquity and at present shows that the hue of soil colour and the content of labile phosphorus prove to be the main cluster-forming characteristics (see Figure 5).

A long agrogenic evolution and the subsequent long-fallow regime do not level the original soil-genetic differences between the soils. While the dark post-agrogenic carbolithosols, despite retaining certain differences in some parts of the area (in the northern part of the Peninsula and near Cape Fiolent), may still be placed in a single cluster, the cinnamonic post-agrogenic (on the Mayachny Peninsula) and the agro-cinnamonic soils, by contrast, differ considerably both from the dark post-agrogenic carbolithosols and from one another.

\section{Conclusion}

During the Holocene, soil evolution in the cinnamonic soils zone of southwestern Crimea is marked by low formation rates of the humus horizon (about $7 \mathrm{~mm} / 100 \mathrm{yr}$ ); an active humus accumulation (about $0.04 \% / 100 \mathrm{yr}$ ); an enrichment of humus in nitrogen; a stabilization of the qualitative humus composition at the level of $\mathrm{C}_{\mathrm{ha}}: \mathrm{C}_{\mathrm{fa}}=0.4-0.7$; a decreasing ratio of labile fractions of humic acids; an accumulation of phosphorus; and an increase in Gibbs free energy.

The hue of soil colour and the content of labile phosphorus prove to be the main cluster-forming characteristics, as indicated by Cluster analysis of soils cultivated in antiquity and at present. The post-agrogenic soils that were exposed to long-term farming have preserved their properties in a number of parameters: eluviation coefficient; $\mathrm{SiO}_{2} /\left(10 \mathrm{R}_{2} \mathrm{O}_{3}\right)$ ratio and Gibbs free energy. The objects are thus individualized through a set of geochemical properties. These criteria secure a reliable identification of the areas involved in the active agricultural use in the vicinity of the ancient Greek and Roman centres, thus facilitating a more objective judgement on the scale of their agricultural expansion and producing capacities - parameters that are essential for every kind of palaeoeconomic reconstructions. The post-agrogenic, long-fallow soils have undergone certain changes in their properties as an effect of long-term natural regeneration, including a decrease in colour brightness; an intensive accumulation of bulk and labile phosphorus; an increase in the content of humus and of $\mathrm{Fe}$ and $\mathrm{Al}$ oxides; a slight decrease in the content of fulvates in the humus; 
and a concentration of diffused elements, particularly Ti, V, Mn and $\mathrm{Zn}$.

Analysis of satellite images (as of 2009) and the application of GIS indicate that, of the total area of the Chersonesean 'nearer' chora divided into plots $(10,660 \mathrm{ha})$, the proportion of land still unaffected by modern-day industrial, building and farming activity has dramatically decreased to $20.5 \%$. This urgently calls for protected status for the area as an object of historical and cultural heritage, both for its archaeological remains and for the agrolandscapes of the ancient city's rural environs.

\section{Funding}

This study was carried out with financial support from the Danish Council for Independent Research | Humanities (grant number 09-069235); and the Belgorod State National Research University, Russia.

\section{References}

Adamesteanu D and Vatin C (1976) L'arrière-pays de Métaponte. CRAI 1976: 110-123.

Atlas počv Ukrainskoj SSR (1979) Kiev: Urožaj.

Bagrov NV and Rudenko LG (eds) (2003) Avtonomnaja Respublika Krym: Atlas. Kiev: Simferopol.

Bagrova LA, Bokov VA, Garkuša LJa et al. (2003) Krymskoe subsredizemnomor'e. In: Mišnev VG and Oliferov AN (eds) Ekosistemy Kryma, ich optimizacija i ochrana. Simferopol: Tavrija, pp. 95-105.

Bilde PG, Bøgh B, Handberg S et al. (2008) Archaeology in the Black Sea Region in Classical Antiquity 1993-2007. Archaeological Reports 54: 115-173.

Bondareva LV (2005) Prirodoochrannaja set' Geraklejskogo poluostrova: Sovremennoe sostojanie i perspektivy. In: Mišnev VG et al. (eds) Ekosistemy Kryma, ich optimizacija i ochrana. Simferopol, pp. 129-138.

Brujako IV, Nazarova NP and Petrenko VG (1991) Drevnie kul'turnye landšafty naj uge Tiligulo-Dnestrovskogo meždureč'ja po dannym aerofotos'emki. In: Vančugov VP (ed.) Severo-Zapadnoe Pričernomor'e - kontaktnaja zona drevnich kul'tur. Kiev: Naukova dumka, pp. 37-44.

Bučas Ju and Danjulajtis G (1984) Agrarnyj landšaft kak kul'turnoe nasledie. Nayčnye trudy vysšich učebnych zavedenij Litovskoj SSR. Geografija 20: 59-67.

Carter JC (2006) Towards a comparative study of chorai west and east: Metapontion and Chersonesos. In: Bilde PG and Stolba VF (eds) Surveying the Greek Chora: Black Sea Region in a Comparative Perspective. Aarhus: University Press, pp. 175-205.

Chtcheglov A (1992) Polis et chora. Cité et territoire dans le Pont-Euxin. Paris: Les Belles-Lettres.

Cordova CE (2007) Holocene Mediterranization of the southern Crimean vegetation: Paleoecological records, regional climate change, and possible non-climatic influences. In: Yanko-Hombach V, Gilbert AS, Panin N et al. (eds) The Black Sea Flood Question: Changes in Coastline, Climate and Human Settlement. Dordrecht: Springer, pp. 319-344.

Cordova CE and Lehman PH (2003) Archaeopalynology of synanthropic vegetation in the chora of Chersonesos, Crimea, Ukraine. Journal of Archaeological Science 30: 1483-1501.

Cordova CE and Lehman PH (2005) Holocene environmental change in southwestern Crimea (Ukraine) in pollen and soil records. The Holocene 15: 263-277.

Cordova CE and Lehman PH (2006) Mediterranean agriculture in southwestern Crimea: Palaeo-environments and early adaptations. In: Peterson DL, Popova LM and Smith AT (eds) Beyond the Steppe and the Sown. Proceedings of the 2002 University of Chicago Conference on Eurasian Archaeology. Leiden-Boston: Brill, pp. 425-447.

Dospechov BA, Vasil'ev IP and Tulikov AM (1987) Praktikum po zemledeliju. Moscow: Agropromizdat.

Elementarnye počvoobrazovatel'nye processy: Opyt konceptual'nogo analiza, charakteristika, sistematika (1992) Moscow: Nauka.

Ena VG, Ena AlV and Ena AnV (2004) Zapovednye landšafty Kryma. Simferopol: Biznes-Inform.

Garbuzov GP, Lisetskii FN and Goleusov PV (2004) Drevnjaja sistema zempleustrojstva u pos. Garkuša (Tamanskij p-ov). Drevnosti Bospora 7: $100-116$.

Gerasimov IP (1949) Koričnevye počvy suchich lesov i kustarnikovych lugostepej. Moscow \& Leningrad.

Goleusov PV and Lisetskii FN (2009) Vosproizvodstvo počv v antropogenno narušennych landšaftach lesostepi. Moscow: GEOS.
IOSPE Latyšev B (1916) Inscriptiones antique orae septentrionalis Ponti Euxini. Vol. I². Petropolis.

Januševič ZV (1986) Kul'turnye rastenija Severnogo Pričernomor’ja. Paleoetnobotaničeskie issledovanija. Kišinev: Štiinca.

Janushevich ZV and Nikolaenko GM (1979) Fossil remains of cultivated plants in the ancient Tauric Chersonesos. Archaeo-physica 8: 115-134.

Judd DB and Wyszecki G (1975) Color in Business, Science, and Industry. New York: Wiley.

Karjaka AV (2008) The demarcation system of the agricultural environment of Olbia Pontike. In: Bilde PG and Petersen JH (eds) Meetings of Cultures in the Black Sea Region: Between Conflict and Coexistence. Aarhus: University Press, pp. 181-192.

Kočkin MA (1967) Počvy, lesa i klimat Gornogo Kryma i puti ich racional'nogo ispol'zovanija. Moscow: Kolos.

Kočkin MA, Važov VI, Ivanov VF et al. (1972) Osnovy racional'nogo ispol'zovanija počvenno-klimatičeskich uslovij v zempledelii. Moscow: Kolos.

Kovalevskaja LA (1994) Raboty na zemel'nom nadele 341 i linii vodoprovoda v Sarandinakinoj balke. In: Kutajsov VA et al. (eds) Archeologičeskie issledovanija v Krymu 1993 g. Simferopol, pp. 137-141.

Kravčenko EA (2005) Katalog poselenij kizil-kobinskoj kul'tury Geraklejskogo poluostrova VI-IV vv. do n.e. In: Zubar' VM, Bujskich AV, Kravčenko EA et al. (eds) Chersones Tavričeskij v tret'ej četverti VI-seredine I vv. do n.e. Kiev: Akademperiodika, pp. 547-553.

Lisetskii FN (1998) Autogenic succession of steppe vegetation in postantique landscapes. Russian Journal of Ecology 4: 217-219.

Lisetskii FN (2008) Agrogenic transformation of soils in the dry steppe zone under the impact of antique and recent land management practices. Eurasian Soil Science 8: 805-817.

Lisetskii FN and Ergina EI (2010) Soil development on the Crimean Peninsula in the late Holocene. Eurasian Soil Science 6: 601-613.

Liu G, Li L, Wu L et al. (2009) Determination of soil loss tolerance of an entisol in Southwest China. Soil Science Society of America Journal 73: $412-417$.

Ljuri DI, Gorjačkin SV, Karavaeva NA et al. (2010) Dinamika sel'skochozjastvennych zemel' Rossii $v$ XX veke i postagrogennoe vosstanovlenie rastitel'nosti i počv. Moscow: GEOS.

Moiseev LA (1926) Sledy irrigacii, melioracii i vodosnabženija drevnego Chersonesa na Geraklejskom poluostrove. Zapiski Krymskogo obščestva estestvoispytatelej 9: 115-122.

Monachov SJu (1989) Amfory Chersonesa Tavričeskogo IV-II vv. do n.e. Saratov: Izdatel'stvo Saratovskogo universiteta.

Nikolaenko GM (1999) Chora Chersonesa Tavričeskogo. Zemel'nyj kadastr IV-III vv. do n.e. Part I. Sevastopol.

Nikolaenko GM (2001a) Chora Chersonesa Tavričeskogo. Zemel'nyj kadastr IV-III vv. do n.e. Part II. Sevastopol.

Nikolaenko GM (2001b) The adjacent Chora of Tauric Chersonesos in the 4th century BC. In: Tsetskhladze GR (ed.) North Pontic Archaeology: Recent Discoveries and Studies. Leiden-Boston-Köln: Brill, pp. 177-204.

Nikolaenko GM (2006) The Chora of Tauric Chersonesos and the Cadastre of the 4th-2nd century BC. In: Bilde PG and Stolba VF (eds) Surveying the Greek Chora: Black Sea Region in a Comparative Perspective. Aarhus: University Press, pp. 151-174.

Oertel AC (1961) Relation between trace-element concentrations in soil and parent material. Journal of Soil Science 12: 119-128.

Podgorodeckij PD (1988) Krym: Priroda. Simferopol: Tavrija.

Polevoj opredelitel' počv (2008) Moscow: V.V. Dokuchaev Soil Science Institute.

Polupan MI, Solovej VB, Kysil' VI et al. (2005) Vyznačnyk ekologogenetyčnogo statusu ta rodjučosti gruntiv Ukrainy. Kyiv: Koloobig.

Počvy Krymskoj oblasti (1969) Simferopol: Krym.

Sandor JA and Eash TS (1995) Ancient agricultural soils in the Andes of Southern Peru. Soil Science Society of America Journal 59: 170-179.

Savelja OJa (1996) Archaeologičeskie materialy k istorii Geraklejskogo poluostrova dokolonizacionnogo perioda. Chersonesskij sbornik 7: $13-18$.

Ščeglov AN (1980) Utilisation de la photographie aérienne dans l'étude du cadastre de Chersonésos Taurique (IVe - IIe s. av. n.è.). Dialogues d'histoire ancienne 6: 59-72.

Shaw DM (1964) Interprétation geochimique des éléments en traces dans les roches cristallines. Paris: Masson.

Šiškin KV (1982) Aerometod kak istočnik dlja istoričeskoj topografii Ol'vii i ee okrestnostej. Sovetskaja archeologija 3: 235-242.

Stojanov RV (2007) Neskol'ko zamečanij o vremeni i pričinach osnovanija Chersonesa Tavričeskogo. Vestnik Drevnej Istorii 2: 125-144.

Stolba VF (2005a) Hellenistic Chersonesos: Towards establishing a local chronology. In: Stolba VF and Hannestad L (eds) Chronologies of the Black 
Sea Area in the Period c. 400-100 BC. Aarhus: University Press, pp. $153-177$.

Stolba VF (2005b) Monetary crises in the early Hellenistic Poleis of Olbia, Chersonesos and Pantikapaion. A re-assessment. In: Alfaro C, Marcos C and Otero P (eds) XIII Congreso Internacional de Numismática (Madrid, 2003). Actas. Madrid: Ministerio de Cultura, pp. 395-403.

Stolba VF (2005c) The oath of Chersonesos and the Chersonesean economy in the early Hellenistic period. In: Archibald ZG, Davies JK and Gabrielsen V (eds) Making, Moving and Managing. The New World of Ancient Economies, 323-31 BC. Oxford: Oxbow, pp. 298-321.

Strželeckij SF (1958) Usad'by klerov Chersonesa Tavričeskogo II v. do n.e. Sovetskaja archeologija 4: 154-169.

Strželeckij SF (1961) Klery Chersonesa Tavričeskogo: K istorii drevnego zemledelija v Krymu (Chersonesskij sbornik 6). Simferopol: Krymizdat.

Ukazanija po klassifikacii i diagnostike počv. V. Počvy vlažnych i polusuchich subtropičeskich oblastej SSSR (1967). Moscow: Kolos.

Vinogradov JuG and Zolotarev MI (1999) Chersones iznačal'nyj. In: Podosinov AV (ed.) Drevnejšie gosudarstva Vostočnoj Evropy 19961997. Moscow: Nauka, pp. 91-129.
Yanuchevitch Z, Nikolayenko G and Kuzminova N (1985) La viticulture à Chersonèse de Tauride aux IVe-IIe siècles av. n. è. d'après les recherches archéologiques et paléoethnobotaniques. Revue archéologique 1: 115-122.

Yena A, Drescher A, Prots B et al. (2006) Biodiversity and transformation: A Crimean affair. Romanian Review of Regional Studies. Journal of the Centre for Regional Geography 2(1): 3-22.

Zacharov SA (1929) Kurs počvovedenija. S priloženiem klassifikacionnych tablic i schematičeskoj karty počvennych zon SSSR, Kavkaza i Š̌A. Moscow: Sel'chozgiz.

Zolotarev MI (1996) Sur la chronologie de Chersonésos à l'époque archaïque. In: Fraysse A, Geny E and Khartchilava T (eds) Sur les traces des Argonautes. VIe Symposium de Vani (Colchide) 22-29 septembre 1990. Paris: Annales Littéraires de 1’Université de Besancon, 613; Diffusé par Les Belles Lettres, pp. 311-317.

Zubar' VM and Kravčenko EA (2003) Interpretation of a group of archaeological sites in the vicinity of Tauric Chersonesos. In: Bilde PG, Højte JM and Stolba VF (eds) The Cauldron of Ariantas. Studies Presented to A.N. Šceglov on the Occasion of his 70th Birthday. Aarhus: University Press, pp. 185-195. 